UDC 577.112:616

\title{
EFFECT OF METHYL TERTIAL BUTYL ETHER ON THE EXPRESSION OF mRNA CODING FOR 6-PHOSPHOFRUCTO-2-KINASE/FRUCTOSE-2,6- BISPHOSPHATASE-3 AND VEGF IN RAT LIVER AND LUNG
}

\begin{abstract}
D. O. Minchenko ${ }^{1}$, K. Tsuchihara ${ }^{2}$, O. P. Yavorovsky ${ }^{3}$, A. V. Kundieva' ${ }^{1}$, Y. O. Paustovsky ${ }^{3}$, H. Esumi ${ }^{2}$, O. H. Minchenko ${ }^{1,2}$

${ }^{1}$ Palladin Institute of Biochemistry, NAS of Ukraine 9, Leontovych St., Kyiv 01601, Ukraine e-mail: ominchenko@yahoo.com

${ }^{2}$ Research Center for Innovative Oncology, National Cancer Center Hospital East Kashiwa, Japan; 6-5-1 Kashiwanoha, Kashiwa, Chiba, 277-8577, Japan

${ }^{3}$ O.O. Bohomoletz National Medical University, 13, Shevchenko Boulvd., Kyiv 01601, Ukraine

Methyl tertial butyl ether, an oxygenated compound of gasoline, is a toxic and ecologically dangerous chemical compound with an ability to introduce a variety of neurotoxic, allergic and respiratory diseases, as well as cancer and leukemia. We used RT/PCR or quantitative PCR to study the effect of methyl tertial butyl ether (everyday injection for one month) on the expression of mRNA coding for 6-phosphofructo-2-kinase/fructose-2,6bisphosphatase-3 (PFKFB-3) and vascular endothelial growth factor (VEGF), which are important for tumor growth and metastasis in the lung and liver. The level of PFKFB-3 and VEGF mRNA expression was increased in the liver in methyl tertial butyl ether treated rats with respect to the control animals. However, methyl tertial butyl ether had opposite effect on the expression of PFKFB-3 and VEGF mRNA in the lung: with strong induction of PFKFB-3 and suppression of VEGF mRNA expression. Moreover, alternative splicing of PFKFB-3 mRNA was changed in methyl tertial butyl ether treated rats in organ specific manner. Thus, methyl tertial butyl ether induces alternative splicing of PFKFB-3 mRNA accompanied by appearing of variants with longer $\mathrm{C}$-terminus in the liver, and with shorter $\mathrm{C}$-terminus in the lung. The results of this investigation clearly demonstrate that methyl tertial butyl ether affects in organ-specific manner the expression and alternative splicing of mRNA coding for PFKFB-3 and VEGF, key regulatory factors of glycolysis, and angiogenesis.
\end{abstract}

Key words: PFKFB-3, VEGF, mRNA, alternative splicing, methyl tertial butyl ether, lung, liver, rats.

\section{INTRODUCTION}

Methyl tertial butyl ether is a representative of numerous oxygenated compounds which are available in gasoline and can to reduce vehicle exhaust emissions, aromatic 
compound content, and avoid using organo-lead compounds, while maintaining high octane number. Immediately after the introduction of methyl tertial butyl ether into gasoline, many consumers of that product in USA and other countries have been getting a variety of neurotoxic, allergic and respiratory diseases [1-3]. Methyl tertial butyl ether causes different cancers in rat and mice $[1,3]$. The precise mechanisms of methyl tertial butyl ether toxic effects leading to development of different diseases, especially cancer, remain poorly understood. Data exist that 6-phosphofructo-2-kinase/fructose-2,6-bisphosphatase (PFKFB) and vascular endothelial growth factor (VEGF) are very important for tumor growth and metastasis and that methyl tertial butyl ether affects the expression of PFKFB-4 mRNA and its alternative splicing, as well as the expression of Per2, BMal1, Clock, and some protein kinases responsible for regulation of key metabolic processes [4-9]. Disturbance in expression of these genes can impair cellular signaling pathways and lead to developing of different pathological processes and cancer, in particular.

The homodimeric bifunctional enzyme PFKFB [6-phosphofructo-2-kinase (EC 2.7.1.105) and fructose-2,6-bisphosphatase (EC 3.1.3.46)] are key enzymes in regulation of glycolysis, as well as gluconeogenesis in normal and different pathological conditions, in particular in malignant tumors, since they control cellular level of fructose2,6-bisphosphate [10-13]. The fructose-2,6-bisphosphate is considered to be the key activator of glycolysis that controls glucose utilization [11, 14, 15]. PFKFB has two distinct catalytic sites on each subunits, one for the 6-phosphofructo-2-kinase activity and the other for the fructose-2,6-bisphosphatase activity $[11,13,16,17]$. PFKFB is a key enzyme in the regulation of glycolysis in malignant tumors [17-21].

There are at least four different PFKFB isoenzymes (PFKFB-1, -2, -3 and -4) in mammals and they are encoded by four independent genes (pfkfb1, pfkfb2, pfkfb3 and pfkfb4) $[2,13,14]$. The PFKFB-3 has eight alternative splice variants with heterogeneity of the regulatory carboxyl-terminus and they are strongly expressed in cancer cells [5, 19, 22-24]. By setting the intracellular fructose-2,6-bisphosphate concentration, PFKFB3 controls glycolytic flux to lactate and the non-oxidative pentose shunt, and is selectively required for the tumorigenic growth of ras-transformed cells $[4,5,19,25]$.

An enhanced glycolysis is observed in different cells under hypoxic conditions and in malignant tumors. It is dependent on PFKFB expression and phosphorylation via hypoxia inducible factor (HIF) even at conditions of normal oxygen tension [5, 15, 19, 20]. Transcription factor HIF plays a central role in coordinating many transcriptional adaptations to hypoxia and is an important mediator of Warburg effect in tumors [6, 15, 34, 39-41]. Many genes whose expression is regulated by hypoxia, in particular vegf and pfkfb3, are overexpressed in malignant cells and contain HIF-1 binding site (hypoxiaresponsible element) $[15,20]$.

Vascular endothelial growth factor (VEGF) is a very important factor of angiogenesis and is elevated in malignant tumors and different cell lines at hypoxic conditions $[5,15,20,23]$. Induction of its expression is tightly connected with overexpression of PFKFB isozymes and enhanced glycolysis in malignant tumors, as well as in different cells at hypoxic conditions [10, 12, 21, 23]. Moreover, HIF, VEGF and PFKFB have a key role in the neoplastic transformation. In turn, most PFKFB isozymes are regulated by a complex network of kinases, phosphatases and metabolites [5, 11, 17, 19].

The expression of PFKFB-3 and VEGF mRNA and its splice variants in different organs of methyl tertial butyl ether treated rats was not studied yet, although significance of PFKFB-3 and VEGF in the regulation of glycolysis, angiogenesis and malignant

ISSN 1996-4536 • Біологічні Студії / Studia Biologica • 2009 • Том 3/№2 • С. 5-14 
transformation is well known. The main goal of this study was to investigate the effect of methyl tertial butyl ether on the expression of mRNA coding for PFKFB-3 and VEGF, as well as the expresssion of its alternative splice variants in rat liver and lung. That is necessary for identifiation of possible target sites of methyl tertial butyl ether which is considered to be an ecologically dangerous chemical compound.

\section{MATERIALS AND METHODS}

Animals. Male Wistar rats (initial body weight 180-200 g) were treated with methyl tertial butyl ether $(500 \mathrm{mg} / \mathrm{kg})$ ones per day for a month in cold stress conditions. In one month, control and methyl tertial butyl ether treated animals were killed and their tissues were frozen in liquid nitrogen before RNA extraction.

RNA isolation. RNA was isolated from the liver and lung by using acid guanidinium-phenol-chlorophorm extraction method of Chomczynski and Sacchi, as described [10].

Expression of PFKFB-3 and VEGF mRNA. The expression of PFKFB-3 mRNA was examined by polymerase chain reaction (PCR) of corresponding cDNA. SuperScript II Reverse Transcriptase, („Invitrogen”, USA) and oligo(dT) were used for cDNA synthesis. Reverse transcription was performed according to the manufacturer's protocol, by using $0.4 \mu \mathrm{g}$ of total RNA. The amplification of PFKFB-3 cDNA ( $1 \mu \mathrm{l}$ of reverse transcription product that corresponds $20 \mathrm{ng}$ of total RNA was used for reverse transcription) was performed with HotStarTaq Master Mix Kit (“QIAGEN”, USA) and „MasterCycler Personal” („Eppendorf”, Germany).

PCR amplification of PFKFB-3 for analysis of splice isoforms was performed by using two forward primers 5'-CTGGAGCCTGTGATCATGG-3' (M3) or 5'-GGTGACACTATTGCGTCTC-3' (M4) and one reverse primer: 5'-GTGGAGTCCATTTACTTG-3' (M5). These oligonucleotides correspond to sequences 1513-1531 and 1680-1707 (forward primers) and 2140-2122 (reverse primer) of the published rat PFKFB-3 cDNA (GenBank accession number NM_057135), corresponding.

PCR amplification of glyceraldehyde 3-phosphate-dehydrogenase (GAPDH) was performed by using forward primer 5'-ATCTTCCAGGAGCGAGATCC-3' and reverse primer 3'-TCATGGATGACCTTGGCCAG-5'. These oligonucleotides correspond to sequences 291-310 and 562-543 of the published rat GAPDH cDNA (GenBank accession number X02231).

PCR amplification of VEGF was performed by using forward primer 5'-AACCATGAACTTTCTGCTCTC-3' and reverse primer 3'-GACAAGCCAAGGCGGTGAGCC-5'. These oligonucleotides correspond to sequences 1011-1031 and 1642-1662 of the published rat VEGF cDNA (GenBank accession number NM_031836). PCR amplification of alternative splice variant of VEGF (GenBank accession number AY702972) was performed by using forward primer 5'-TGCCCCTAATGCGGTGTGCG-3' and reverse primer 5'-GTGGTCACTTACTTTTCTGGC-3'. These oligonucleotides correspond to sequences 230-249 and 411-431 of the published rat VEGF cDNA of this unique alternatively splice variant. The primers were purchased from „Sigma”.

$\beta$-actin mRNA expression was used as a loading control of analyzed RNA [23]. The polymerase chain reaction products were analyzed by electrophoresis in agarose gel and stained with the ethidium bromide. 
Quantitative polymerase chain reaction was performed on „Stratagene Mx 3000P cycler”, using SYBRGreen Mix and specific sets of primers for PFKFB-3 (forward 5'-TGGACGACTTCATGAAGAG-3' and reverse - 5'-GCATTGGCGAACTTCTTGC-3'; the nucleotide sequences of these primers correspond to sequences 956-974 and 1247-1229 of rat PFKFB-3 cDNA; GenBank accession number NM_057135) and VEGF, as described previously [23]. Reaction was performed in triplicate. Analysis of quantitative PCR was performed by using special computer program „Differential expression calculator" and statistical analysis in the Excel program.

\section{RESULTS AND DISCUSSION}

As shown in Fig. 1, the levels of mRNA coding for PFKFB-3 and VEGF, are significantly increased in liver of methyl tertial butyl ether treated rats with respect to the control animals. However, methyl tertial butyl ether had opposite effect towards the expression of PFKFB-3 and VEGF mRNA in the lung: strong induction of PFKFB-3 (+119\%) and suppression of VEGF (-25\%) mRNA. Besides, we have studied the expression of alternative splice variants and two sets of primers specific for $3^{\prime}$-coding region of PFKFB-3 mRNA. Thus, our results suggest that methyl tertial butyl ether enhances glycolysis via inducing PFKFB-3 expression. These results agree with data about key role of PFKFB-3 in enhancing glycolysis [14, 15, 17, 19, 20]. Moreover, methyl tertial butyl ether strongly induces expression of GAPDH mRNA, both in liver and lung (Fig. 2), that is also induced at conditions of enhanced glycolysis [15].

Fig. 2 shows two main bands of PFKFB-3 cDNA in the liver and lung of control and methyl tertial butyl ether treated rats revegled with M3 and M5 primers. Methyl tertial butyl ether increases the expression of PFKFB-3 mRNA variants of upper band in the liver and lower band - in the lung. Fig. 3 demonstrates similar results with another set of primers (M4 and M5), however, two additional bands of PFKFB-3 cDNA were identified.

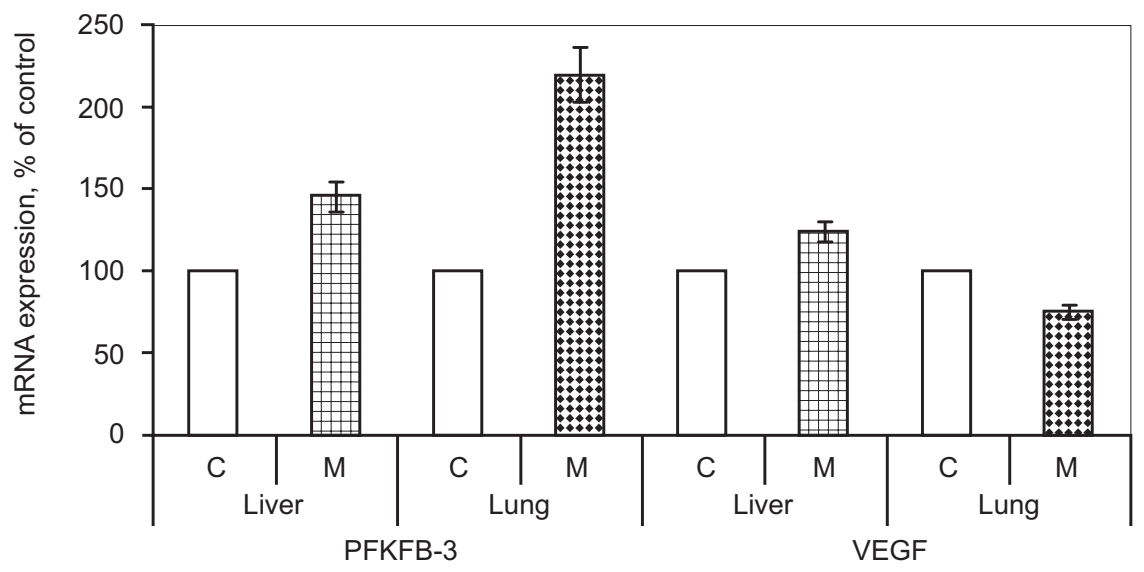

Fig. 1. Analysis of 6-phosphofructo-2-kinase/fructose-2,6-bisphosphatase-3 (PFKFB-3) and vascular endothelial growth factor (VEGF) mRNA expression in the liver and lung of control (C) rats and rats treated with methyl tertial butyl ether (M) everyday for one month. Quantitative polymerase chain reaction was used $(n=4)$. Amplification of PFKFB-3 mRNA was carried out by using M1 forward and M2 reverse primers. Values of PFKFB-3 and VEGF mRNA expressions were normalized to the level of $\beta$-actin mRNA expression 


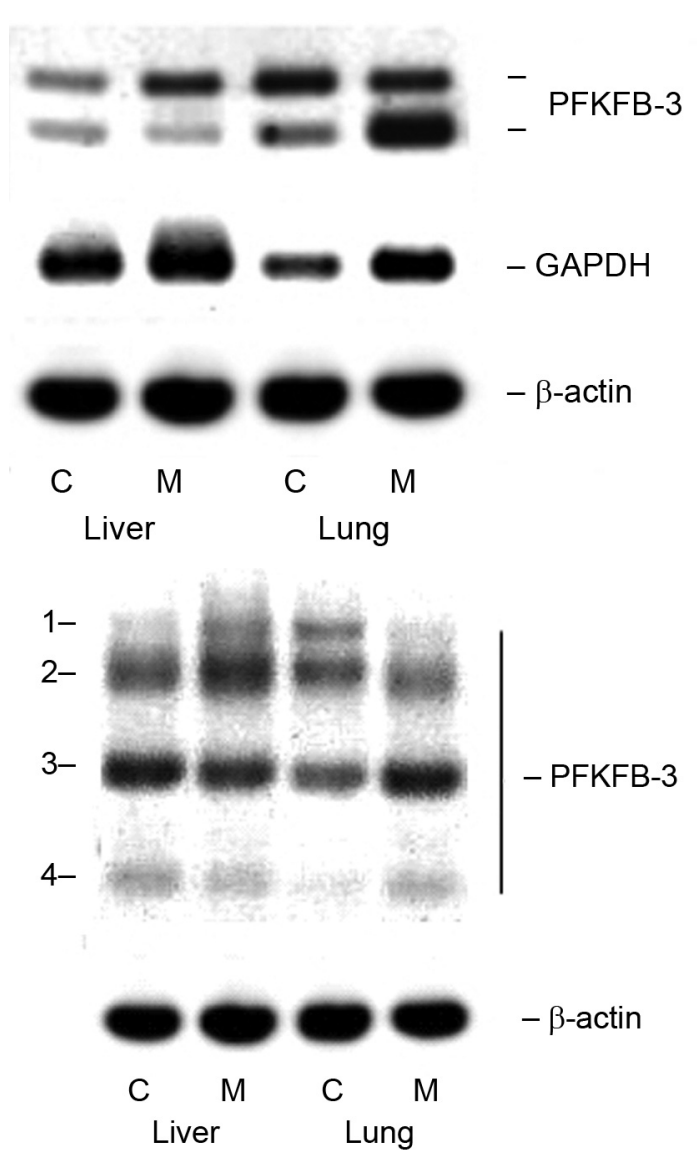

Fig. 2. Analysis of PFKFB-3 and GAPDH mRNA expression in the liver and lung of control (C) and animals treated with methyl tertial butyl ether (M), using RT-PCR. Amplification of PFKFB-3 mRNA was carried out using M3 forward and M5 reverse primers. Amplified products were analyzed by electrophoresis in the agarose gel. The $\beta$-actin mRNA expression was used to standardize loading RNA quantity. A representative (of four) gel electrophoresis is shown

Fig. 3. Analysis of PFKFB-3 mRNA expression in the liver and lung of control (C) and animals treated with methyl tertial butyl ether (M), using RT-PCR. Amplification of PFKFB-3 mRNA was carried out by using M4 forward and M5 reverse primers. Amplified products were analyzed by electrophoresis in the agarose gel. The $\beta$-actin mRNA expression was used to standardize loading RNA quantity. A representative (of four) gel electrophoresis is shown

Alternative splice variants of PFKFB-3 mRNA differ in the exon structure of C-terminal regulatory region (Fig. 4). Two bigger (NM_057135 and D87241-D87243) and three smaller (D87244, D87245 and EU034674) alternative splice variants were revealed. One can see two bands of PFKFB-3 mRNA splice variants: the upper band contains four bigger variants, while the lower band - only two smaller variants (D87244 and D87245). In Fig. 3, one can see four bands. Band 1 contains the biggest alternative splice variants of rat PFKFB-3 mRNA (NM_057135) which has a full set of known exons and additional exons (13a and 15a) of C-terminal regulatory region. Band 2 contains three bigger variant of rat PFKFB-3 mRNA (D87241-D87243). Two of them contain $13^{\text {th }}$ additional exon and one $-15^{\text {th }}$ additional exon (Fig. 4). Two smaller variants which do not have those additional exons are located in the band 3 (Fig. 3). Band 4 of PFKFB-3 mRNA (Fig. 3) contains the smallest splice variant which does not have $14^{\text {th }}$ and $15^{\text {th }}$ exons, as well as $13^{\text {th }}$ and $15^{\text {th }}$ additional exons. There are three stop codons for different alternative splice variants of PFKFB-3 mRNA (Fig. 4). They are resulting in three different types of $\mathrm{C}$-terminus amino acid sequence (Fig. 5).

As shown in Fig. 5, different alternative splice variants of PFKFB-3 mRNA have different quantity and position of serine residues (underlined) in the C-terminus that could have certain significance in regulation of enzymatic activity through serine phosphorylation $[11,18]$. Moreover, three bigger splice variants of PFKFB-3 mRNA (NM_057135, D87241 and D87242) contain an additional exon 13 a (29 amino acid segment), which has six ser- 


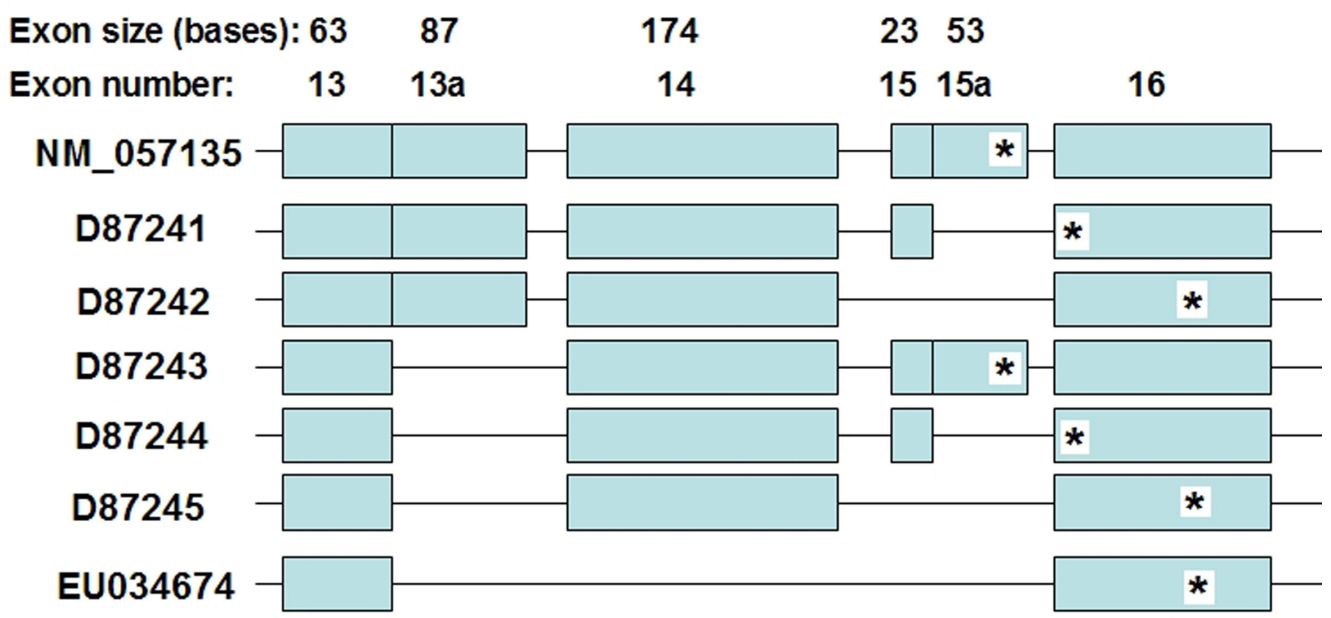

Fig. 4. Exon structure of C-terminal variable region of rat PFKFB-3 mRNA isoform (GenBank accession number MN_057135) which has all known sequence elements (exons and additional exons) is presented. Position of three possible stop codons for different alternative splicing variants of PFKFB-3 mRNA is shown

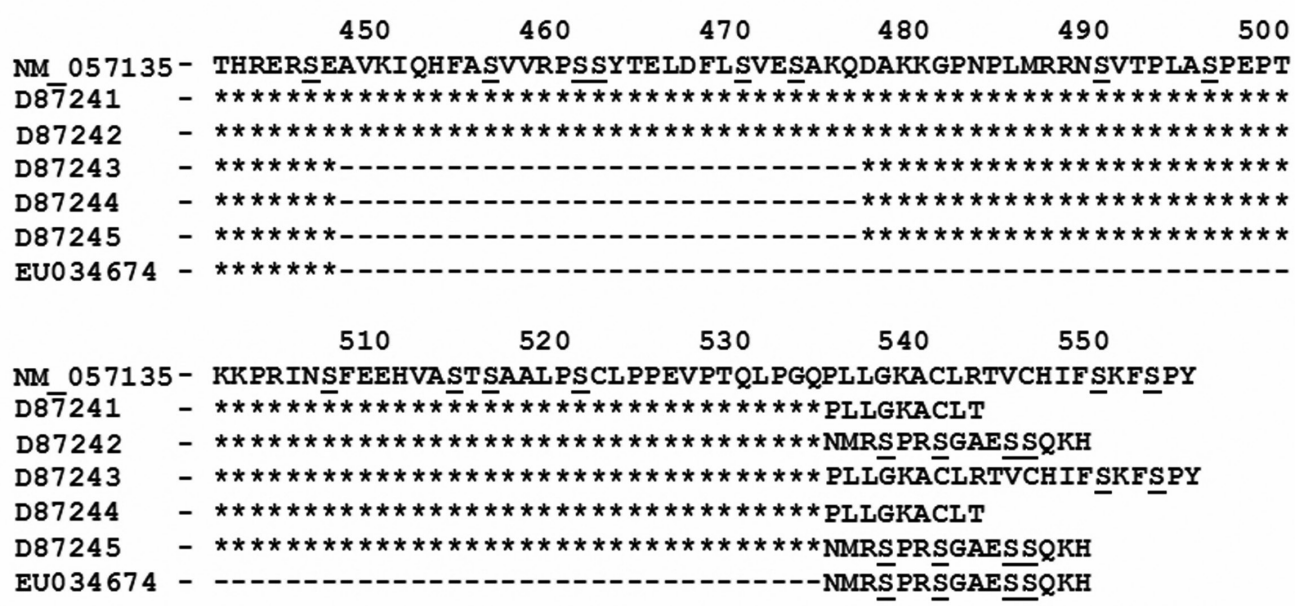

Fig. 5. Schematic presentation and comparison of different rat PFKFB-3 alternative splicing variants. Four splicing variants of PFKFB-3 are shorter missing 29 amino acid segment which contains six serine residues (underlined). Three types of the C-terminus ending for different PFKFB-3 splicing variants are shown

ine residues, however its significance in the regulation of PFKFB-3 activity via phosphorylation has not been studied yet. There are data that phosphorylation of $\mathrm{Ser}^{490}$ is responsible for activation of glycolysis in human cancer [18]. As shown in Fig. 3 the expression of smallest isoform of alternative splicing variant of PFKFB-3 mRNA is decreased in the liver and increased in the lung of methyl tertial butyl ether treated rats with respect to the control animals. Recently, it was shown that expression of this splicing variant is decreased in the heart and lung at diabetes [24].

Thus, methyl tertial butyl ether affects alternative splicing of PFKFB-3 mRNA in organ specific manner. 
The results presented in Fig. 6, clearly demonstrated the existence of additional band of VEGF cDNA in the liver and lung of methyl tertial butyl ether treated animals containing several shorter alternative splicing variants of VEGF mRNA [23]. The level of expression of these alternative splicing isoforms of VEGF mRNA were increased in the liver and lung in rats treated with methyl tertial butyl ether, with respect to the control animals. cDNA of that band was cloned and new alternative splicing variant of VEGF mRNA with 14 bases insert after $5^{\text {th }}$ exon was identified (GenBank accession number AY702972). As shown in Fig. 7, the level of expression of this alternative splicing variant of VEGF mRNA was increased in the liver and lung in rats treated with methyl tertial butyl ether, with respect to the control animals. If shouled be noted that in the liver this induction was much stronger.

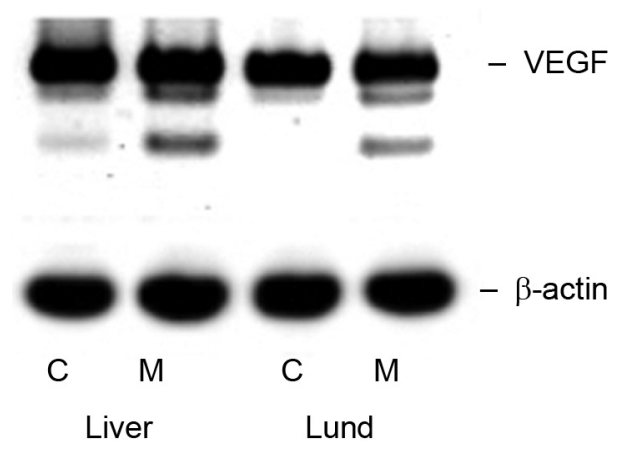

Fig. 6. Analysis of vascular endothelial growth factor (VEGF) mRNA expression in the liver and lung of control $(\mathrm{C})$ and animals treated with methyl tertial butyl ether (M) by using RTPCR. Amplified products were analyzed by electrophoresis in agarose gel. The $\beta$-actin mRNA expression was used for standartization of analyzed RNA quantity. A representative (of four) gel electrophoresis is shown

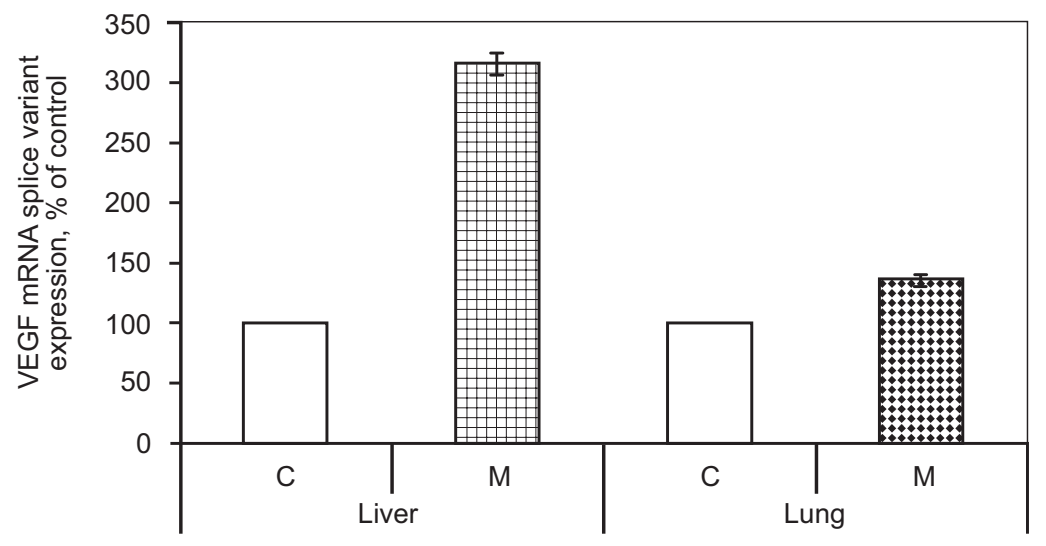

Fig. 7. Analysis of the expression of VEGF mRNA alternative splicing variant (GenBank accession number AY702972) in the liver and lung of control (C) rats and animals treated with methyl tertial butyl ether (M) everyday for one month by using quantitative polymerase chain reaction; $n=3$. Values of VEGF mRNA splicing variant expression were normalized to $\beta$-actin mRNA expression

Thus, the methyl tertial butyl ether, toxic and ecologically dangerous chemical compound affects the expression of PFKFB-3 and VEGF mRNA that can be important regulatory mechanism controlling cell glycolysis and angiogenesis. Besides, the expression of PFKFB-3 and VEGF mRNA alternative splicing variants can be used as sensitive test for detection of toxic action of ecologically dangerous chemical compounds. More focused studies are needed for better understanding mechanisms by which aliphatic ethers, such as methyl tertial butyl ether, can affect health and environment. 
1. McGregor $D$. Ethyl tertiary-butyl ether: a toxicological review. Critical Review Toxicology, 2007; 37(4): 287-312.

2. Hutcheon D. E., Arnold J. D., Hove W., Boyle J. 3rd. Disposition, metabolism, and toxicity of methyl tertiary butyl ether, an oxygenate for reformulated gasoline. Journal of Toxicology and Environmental Health, 1996; 47(5): 453-464.

3. Mehlman M. A. Dangerous and cancer-causing properties of products and chemicals in the oil-refining and petrochemical industry. Part XXII: Health hazards from exposure to gasoline containing methyl tertiary butyl ether: study of New Jersey residents. Toxicology Ind. Health, 1996; 12(5): 613-627.

4. Clem B., Telang S., Clem A. et al. Small-molecule inhibition of 6-phosphofructo-2-kinase activity suppresses glycolytic flux and tumor growth. Molecular Cancer Therapy, 2008; 7(1): 110-120.

5. Atsumi T., Chesney J., Metz C. et al. High expression of inducible 6-phosphofructo-2-kinase/ fructose-2,6-bisphosphatase-3 (iPFK-2; PFKFB3) in human cancers // Cancer Research, 2002; 62(20): 5881-5887.

6. Ferrara N. Vascular endothelial growth factor: basic science and clinical progress. Endocrinology Review, 2004; 25(4): 581-611.

7. Simiantonaki N., Jayasinghe C., Michel-Schmidt R. et al. Hypoxia-induced epithelial VEGFC/VEGFR-3 upregulation in carcinoma cell lines. International Journal of Oncology, 2008; 32(3): 585-592.

8. Minchenko O.H., Yavorovsky O.P., Paustovsky Y.O. et al. Circadian genes as sensitive markers of bioinsecurity. Environment \& Health, 2009; 1(48): 10-17.

9. Minchenko D.O., Mykhalchenko V.G., Tsuchihara K. et al. Unique alternative splice variants of rat 6-phosphofructo-2-kinase/fructose-2,6-bisphosphatase-4 mRNA. Ukrainian Biochemical Journal, 2008; 80(4): 66-73.

10. Minchenko O. H., Opentanova I. L., Minchenko D. O. et al. Hypoxia induces transcription of 6-phosphofructo-2-kinase/fructose-2,6-bisphosphatase 4 gene via hypoxia-inducible factor1alpha activation. FEBS Letters, 2004; 576(1): 14-20.

11. Rider M. H., Bertrand L., Vertommen D. et al. 6-phosphofructo-2-kinase/fructose-2,6-biphosphatase: head-head with a bifunctional enzyme that controls glycolysis. Biochemical Journal, 2004; 381(Pt. 3): 561-579.

12. Minchenko A. G., Leshchinsky I., Opentanova I. L. et al. Hypoxia-inducible factor-1-mediated expression of the 6-phosphofructo-2-kinase/fructose-2,6-bisphosphatase-3 (PFKFB3) gene. Journal of Biological Chemistry, 2002; 277(8): 6183-6187.

13. Bensaad K., Tsuruta A., Selak M.A. et al. TIGAR, a p53-inducible regulator of glycolysis and apoptosis. Cell, 2006; 126: 107-120.

14. Wu C., Khan S.A., Peng L.-J., Lange A. J. Roles for fructose-2,6-bisphosphate in the control of fuel metabolism: beyond its allosteric effects on glycolytic and gluconeogenic enzymes. Advances in Enzyme Regulation, 2006; 46: 72-88.

15. Denko N.C. Hypoxia, HIF1 and glucose metabolism in the solid tumor. Nature Review Cancer, 2008; 8: 705-713.

16. Smith W. E., Langer S., Wu C. et al. Molecular coordination of hepatic glucose metabolism by the 6-phosphofructo-2-kinase/fructose-2,6-bisphosphatase : glucokinase complex. Molecular Endocrinology, 2007; 21(6): 1478-1487.

17. Atsumi T., Nishio T., Niwa $H$. et al. Expression of inducible 6-phosphofructo-2-kinase/fructose-2,6-bisphosphatase/PFKFB3 isoforms in adipocytes and their potential role in glycoIytic regulation. Diabetes, 2005; 54(12): 3349-3357.

18. Bando H., Atsumi T., Nishio T. et al. Phosphorylation of the 6-phosphofructo-2-kinase/fructose 2,6-bisphosphatase/PFKFB3 family of glycolytic regulators in human cancer. Clinical Cancer Research, 2005; 11(16): 5784-5792.

19. Chesney J. 6-phosphofructo-2-kinase/fructose-2,6-bisphosphatase and tumor cell glycolysis. Current Opinion Clinical Nutritional Metabolism Care, 2006; 9(5): 535-539. 
20. Bartrons R., Caro J. Hypoxia, glucose metabolism and the Warburg's effect. Journal of Bioenergy and Biomembranes, 2007; 39(3): 223-229.

21. Minchenko O., Opentanova I., Caro J. Hypoxic regulation of the 6-phosphofructo-2-kinase/ fructose-2,6-bisphosphatase gene family (PFKFB-1-4) expression in vivo. FEBS Letters, 2003; 554(3): 264-270.

22. Duran J., Gómez M., Navarro-Sabate A. et al. Characterization of a new liver- and kidneyspecific pfkfb3 isozyme that is downregulated by cell proliferation and dedifferentiation. Biochemical Biophysical Research Communications, 2008; 367(4): 748-754.

23. Minchenko D.O., Bobarykina A.Y., Senchenko T.Y. et al. Expression of the VEGF, Glut1 and 6-phosphofructo-2-kinase/fructose-2,6-bisphosphatase-3 and -4 in human cancers of the lung, colon and stomach. Studia Biologica, 2009; 3(1): 25-34.

24. Mykhalchenko V.G., Tsuchihara K., Minchenko D.O. et al. 6-Phosphofructo-2-kinase/fructose-2,6-bisphosphatase mRNA expression in streptozotocin-diabetic rats. Biopolymers \& Cell, 2008; 24(3): 260-266.

25. Telang S., Yalcin A., Clem A.L. et al. Ras transformation requires metabolic control by 6-phosphofructo-2-kinase. Oncogene, 2006; 25(55): 7225-7234.

\title{
ВПЛИВ МЕТИЛТРЕТБУТИЛОВОГО ЕФІРУ НА ЕКСПРЕСІЮ MPHК PFKFB-3 I VEGF У ПЕЧІНЦІ ТА ЛЕГЕНІ ЩУРІВ
}

\author{
Д. О. Мінченко ${ }^{1}$, К. Тсучігара", А. В. Кундієва', \\ О. П. Яворовський, Ю. О. Паустовський, Г. Есумї, О. Г. Мінченко \\ 1/нститут біохімії ім. О. В. Палладіна НАН України; \\ вул. Леонтовича, 9, Київ 01601, Україна \\ ${ }^{2}$ Науково-дослідний центр інноваційної онкології Національного онкологічного центру, \\ Кашіва, Японія; 6-5-1 Кашіванога, Кашіва, Чіба, 277-8577, Японія \\ ${ }^{3}$ Національний медичний університет ім. О. О. Богомольця; \\ бульв. Шевченка, 13, Київ 01601, Україна
}

Метилтретбутиловий ефрір є токсичною, екологічно небезпечною хімічною сполукою, що додається до бензину для збільшення октанового числа. Ця сполука здатна ініціювати різні нейротоксичні, алергічні, респіраторні та онкологічні захворювання. Ми досліджували дію метилтретбутилового ефріру на експресію 6-фросфооррукто-2-кінази/ фрруктозо-2,6-бісфросфратази-3 (PFKFB-3) та ендотеліального фрактора росту судин (VEGF) у печінці та легені щурів методом полімеразної ланцюгової реакції. Встановлено, що експресія PFKFB-3 та VEGF, які відіграють надзвичайно важливу роль у рості злоякісних пухлин і їхньому метастазуванні, порушується у печінці та легені щурів, яким вводили метилтретбутиловий ефрір, порівняно з контрольними тваринами. Виявлено органоспецифічний вплив метилтретбутилового ефіру на альтернативний сплайсинг мРНК PFKFB-3: індукцію експресії альтернативних сплайс-варіантів мРНК PFKFB-3 з довгим C-кінцем у печінці та з коротким С-кінцем - у легені. Результати досліджень чітко продемонстрували, що метилтретбутиловий ефрір органоспецифічно порушує експресію і альтернативний сплайсинг PFKFB-3 та VEGF, ключових фракторів регуляції гліколізу й ангіогенезу.

Ключові слова: PFKFB-3, VEGF, мРНК, альтернативний сплайсинг, метилтретбутиловий ефір, легеня, печінка, щур. 


\title{
ВЛИЯНИЕ МЕТИЛТРЕТБУТИЛОВОГО ЭФИРА НА ЭКСПРЕССИЮ МРНК РFКFВ-3 И VEGF В ПЕЧЕНИ И ЛЕГКОМ КРЫС
}

\author{
Д. А. Минченко ${ }^{1}$, К. Тсучигара ${ }^{2}$, А. В. Кундиева', \\ А. П. Яворовский, Ю. А. Паустовский ${ }^{3}$, Г. Эсуми ${ }^{2}$ А. Г. Минченко ${ }^{1,2}$ \\ ${ }^{1}$ Институт биохимии им. А. В. Палладина НАН Украины \\ ул. Леонтовича, 9, Киев 01601, Украина \\ ${ }^{2}$ Научно-исследовательский центр инновационной онкологии \\ Национального онкологического центра, Кашива, Япония; Кашива, Чиба, Япония \\ ${ }^{3}$ Национальный медицинский университет им. А. А. Богомольца \\ бульв. Шевченко, 13, Киев 01601, Украина
}

Метилтретбутиловый эфир является токсичным, экологически опасным химическим соединением, которое добавляется к бензину для увеличения октанового числа и которое способно инициировать различные нейротоксические, аллергические, респираторные и онкологические заболевания. Мы исследовали влияние метилтретбутилового эфрира на экспрессию 6-фоссрофррукто-2-киназы/фруктозо-2,6-биссросфратазы-3 (PFKFB-3) и эндотелиального фактора роста сосудов (VEGF) в печени и легком крыс методом полимеразной цепной реакции. Установлено, что экспрессия PFKFB-3 и VEGF, которые играют важную роль в росте злокачественных опухолей и их метастазировании, нарушается в печени и легком крыс, которым вводили метилтретбутиловый эфрир, в сравнении с контрольными животными. Выявлено органоспецифическое влияние метилтретбутилового эфрира на альтернативный сплайсинг мPHК PFKFB-3: индукцию экспрессии альтернативных сплайс-вариантов мPHК PFKFB-3 с длинным С-концом в печени и с коротким С-концом - в легком. Результаты проведенных исследований четко продемонстрировали, что метилтретбутиловый эфир органоспецифически нарушает экспрессию и альтернативный сплайсинг PFKFB-3 и VEGF, ключевых фракторов регуляции гликолиза и ангиогенеза.

Ключевые слова: PFKFB-3, VEGF, мРНК, альтернативный сплайсинг, метилтретбутиловый эфир, легкое, печень, крыса.

Одержано: 04.08.2009 